\title{
Efficacy of Outside - Classroom English Language Learning: A Study of Intermediate Bengali Medium Students Studying English at Tertiary Level in
} Bangladesh

\author{
Faria Sultana \\ Lecturer, America Bangladesh University \\ Dhaka, Bangladesh \\ E-mail: utpolaborno@gmail.com
}

Received: May 8, 2014 Accepted: May 28, 2014 Published: May 28, 2014

doi:10.5296/ijele.v2i2.5699 URL: http://dx.doi.org/10.5296/ijele.v2i2.5699

\begin{abstract}
The study examined the techniques and the learning strategy of post graduate intermediate Bengali medium learners to improve their English language proficiency. We conducted a survey among 100 students from tertiary level in a Bangladeshi university. The study identified electronic media, subtitle, songs, movies, commentary, newspaper and story books all these were potential medium to improve learners' English language skills. In addition, learners' motivation, awareness, self evaluation, types of materials or facilities that learners' received are the motivators for English language learning at tertiary level learners. All these suggested to consider these factors in developing further curriculum of English language teaching.
\end{abstract}

Keywords: English language, English Language Proficiency, Out-of-class language learning, English for Academic Purpose, Post Graduate Intermediate 


\section{Background}

English use as an official language in many nations and also influence different cultures in a large number of countries. The use of the English language has increased rapidly because of further studies; travel in other countries and also for social and global contact. In the education sectors English language uses for communication with native and non-native speakers. In order to search information and obtain knowledge, to read books English is mandatory and often used as the medium of instruction in higher education.

English has been used in various domains of communication. The demands for English skills are crucial in response to the importance to the impact of globalization (Tsang, 1999). (PGI)Post graduate intermediate Bengali medium learners are giving their efforts to learn English language and to improve their English language proficiency (ELP). Students need suitable orientation and training to use self-access centers effectively (Detaramani and Chan, 1999; Miller, 2000; and Rujikietgumjorn, 2000). An earlier study of language learning showed that beliefs (Cotterall, 1995) where six dimensions were identified as underlying learner responses to a questionnaire, and explored the relationship between each factor and independent language learning behavior. It is notable on Benson (2001: 62) research which is about out-of-class language learning (OCLL), and its importance to the theory and practice of autonomy. OCLL research framework is broad the meaning is to some extent precise. Based on inside the classroom language learning many research areas have been investigated in the past. Target language community has been made students notification about L2 registers which helps to develop learner's proficiency (Scarcella and Oxford, 1992:183). Some research attention focused based on the language learners role .learners' individualised study programs has specifically focused by Victori and Lockhart(1995)which was case study research. Along with the interaction of learner autonomy and metacognition and language learning, learners' training was highlighted in their findings. Cotterall (1999) sought to identify the beliefs of English language students regarding variables that influence language learning and she found that students rated practice and opportunities to use the target language ahead of the teacher in terms of their importance for successful language learning. Motivation and metacognition manipulate learner behaviour (Pickard 1995, Victori and Lockhart 1995, Ushioda 2001, Yorozu 2001, Wenden 2001, Lamb 2002).

There are several factors that inspired students to develop English from outside of the classroom as a foreign or second language in a non-native speaking country as Bangladesh. Those factors may derive from many components including social environmental issues, the difference of culture, social economic extension, teacher student relation etc. So this paper has a main purpose to identify what Bengali medium post graduate intermediate learner do outside of the class to develop their English language proficiency (ELP). The purpose of this study was to examine the techniques and the learning strategy of post graduate intermediate (PGI) Bengali medium learners to improve their English language proficiency (ELP). 


\section{Research Methodology}

The study conducted during a ten-week English for Academic Purposes with a survey of (100) students (female $=48$ male $=52$ ). All the survey respondents were aged $18-20$ years or younger. All the students were from private universities $1^{\text {st }}$ semester to $4^{\text {th }}$ semester. Students were selected from different department but they were all from hundred level English course. All the students were Bangladeshi but they came from different district. The aim of the study was to investigate the potential benefits to be gained in terms of language learning from watching sub-titled programmes. The subjects provided detailed feedback on language gained from the programmes, on their reactions to the sub-titles, on strategies used in exploiting the sub-titles, on levels of anxiety, on the comprehensibility of the sound and text, and on the programmes themselves. There were no specific sampling procedures employed in this paper. Regarding the reliability of self-report was that the interviews of subjects in the longitudinal study, and the final survey of this paper, were all conducted in English. The reason behind of conducting interviews in English was that researchers or policy makers can involved directly without translation. This study also provided motivation for the students who participated. And, also works as a good opportunity to develop their language skills.

\section{Results}

The aim of this study was to verify/identify what PGI Bengali medium learners did outside of classroom to improve their ELP. The study was descriptive rather than experimental. The participants reported altogether 100. The study focused one question which was 'How do Bengali medium learners use their opportunities outside of the classroom for developing their English language proficiency?'

\subsection{Conversation}

Conversation was found another important and interesting way to improve learners' English language efficiency. Majority of the students opined that English conversation had less contribution to develop their writing skill rather enriched their speaking skill along with sentence making capability and mostly used grammatical structures, which is required for the conversation. Thus way their hesitation becomes less.

Over half of the respondents (90) mentioned that they used mainly Bengali language when they talk with their friends and at home. Nearly 50 students indicated that they tried to use mainly English while they are at the university classroom. A further 30 people indicated that they used equal proportions of English and Bengali. Several students mentioned that they were able to focus more sharply on personal language needs outside of class than inside of the class. From the findings it is suggested that sub-titled programmes may be of limited value for low-level learners, but may provide large amounts of comprehensible input for post-intermediate-level learners. The findings also indicated that sub-titles promote a low affective filter, encourage conscious language learning in 'literate' learners, and, paradoxically, release spare language-processing capacity. 


\subsection{Electronic Media}

We investigated caption use, sound, and the reading behavior of 100 students who had just completed secondary examination. The study indicated that beginning readers recognize more words when they view television that uses captions. The auditory element was important for comprehension tasks related to incidental elements to the majority of the respondents. In addition, spontaneous use of target words, the combination of captions and sound helped learners to identify the critical story elements in the video clips.

\subsection{Subtitle}

In this study, 45 learners were from the dept. of English and rest of the learners was from different departments. More than $60 \%$ said that the subjects also undertook a limited number of language-oriented activities connected with the programmes. Students reported in the beginning of their tertiary level, they watched a movie, drama, television programs with English language subtitles. Nearly three fourths of the learners found that the sub-titles are useful and beneficial to learners' language development.

\subsection{Songs}

For almost every student it is very common to listen and enjoying songs which has been a quite innovative nature of human behavior and lyrics are available of each song. $70 \%$ learners mentioned that by reading lyrics and listening words several times not only helps to pass their leisure time but also plays an important role to improve their vocabulary and to understand the meaning of English songs. The majority of the respondents perceived that their vocabulary increased by continuous listening of English songs which actually helped them for developing and adopting the English language skill (ELS) outside of the classroom by themselves.

\subsection{Movies}

We found that between 18-20 age group learners preferred to watch different type of movies e.g. romantic, horror, action, adventure and art film. But there is difference between male and female students preference in selecting movies. Most of the learners replied that movies always not only increase their vocabulary to get the correct meaning of its own but still at least a huge parentage of them get its correct meaning and in the same process the grammatical structure of the sentence making gets developed automatically.

\subsection{Commentary}

Watching and listening to sports has been a very easy of entertainment for all ages nowadays. Nearly two third of the respondent mentioned that they preferred to watch sports .Among them majority of the learners reported that they found significant improvement in their English language listening skill. Because of universalness the whole telecast is often done in English and people watching and listening to it time to time. In fact for a longer period rather than the above discussed media it becomes a very effective way to achieve the goal of increasing the efficiency level of EL learning for post graduate bangle medium learners. Actually the seed lies in practicing which depends on different ways but the longer and the 
often one goes the distance and achieve the goal.

\subsection{Newspaper and Story Books}

Reading newspaper and story books is another vital and common way for post graduate bangle medium learners' to develop English language skills. More than 80\% learners' reported that specifically by reading English newspaper and English story books their writing skills developed a lot. Along with that learners' vocabulary also enriched. English newspaper and the story books gather attention rather than the textbooks often toward the student whom actually at the perfect age for the language development. The vocabulary automatically enriched because of the human nature for knowing and understanding by guessing and sometimes from the dictionary and at least $50 \%$ gets their space in the hard disk of human brain and they automatically get used up when practicing it.

\section{Discussion}

The study found that many students devoted considerable time to studying and practicing English outside the classroom, much of this time was spent on more receptive activities such as listening and reading, rather than speaking. Post intermediate Bengali medium students face great difficulties when they entered university for higher education. Nevertheless, students are generally weak in English and found difficulties in English language learning especially where native language is Bengali due to the differences of social context and cultural environment.

Television might be a popular medium for the tertiary level learners to improve their ELS. Therefore those who are working in the television programmes they should be more careful about their programme that they are telecasting. It seems that watching television appeared to facilitate the recognition of words to improve beginner tertiary level learners' oral reading rates. Television captions, by evoking efforts to read, appeared to help a learner to focus on central story elements and away from distracting information, including sound effects and visual glitz like the English songs, English movies are more effective in the process of developing English language skills. It has been a common phenomenon that everybody goes to the English movies for quality entertainment not only from Hollywood but also from some well-organized serial makers of Europe produce high quality movies which actually create a very huge field of attraction for all the aged group of people even in rural areas. It is a common desire to know and understand what people are watching and why the storyline goes like this. From this fact it starts with predicting the meanings and then at time two times when they enjoy movies their vocabulary get enriched. Post intermediate Bengali medium learners effort on study and practice will always vary to improve their ELP. Some learners have the capacity to improve their ELP by themselves. For this reason from the beginning, children need to learn different reading strategies in the primary school level (Sultna 2013). Teachers and researchers need to develop further methodical approaches to the types of knowledge that learners gain out of class, and a more detailed understanding of what contributes to learning to teach. In the Bengal medium school, the majority of the teachers follow GTM (Grammar Translation Method) that is knowledge based teaching method but not performance (Sultana, 2013). Because of their background learners are suffering from lack of confidence and some differences among learners which might not be overcome easily. To develop English 
language proficiency learners beliefs are very important. Electronic media, subtitle, songs, movies, commentary, newspaper and story books all these are potential medium to improve learners' English language skills. In addition, learners' motivation, awareness, self evaluation, types of materials or facilities that learners' received are the motivators for English language learning at tertiary level learners. Pedagogy has the capacity to provide the opportunities and conditions within which these learners' contributions are found to have a positive effect upon learning or may be more fully engaged (Breen 2001, Arnold, 1988).

\section{Acknowledgement}

The research was financed by the author herself. We are thankful to all of the participants for their voluntary participation.

\section{References}

Benson, P. (2001). Teaching and researching autonomy in language learning. Harlow: Pearson Education

Breen, M. P. (Ed). (2001). Learner contributions to language learning. Harlow: Pearson Education Limited.

Cotterall, S. (1999). Key variables in language learning: what do learners believe about them? System, 27, 493-513.

Detaramani, C., \& I S I Chan. (1999). Learners' needs, attitudes and motivation towards the self-access mode of language learning. RELC Journal, 30(1), 124-157.

Lamb, M. (2002). Explaining successful language learning in difficult circumstances. Prospect, 17(2), 33-52.

Pickhard, N. (1995). Out-of-class-language learning strategies: three case studies. Language Learning Journal, 12(Sept.), 35-37.

Scarcella, R C., \& R L Oxford. (1992). The tapestry of language Learning. Boston:Heinle \& Heinle.

Sultana, F., \& Ahsan, M. A. (2013). Efficacy of Communicative Language Teaching in Primary School - Bangladesh Context. International Journal of English Language Education; 2013, Vol 2, No. 1. http://dx.doi.org/10.5296/ijele.v2i1.4734

Tsang, E. S. (1999). Resistance to self-access learning. Iin Morrison, B. J. (Ed.), Experiments and evaluation in self-access language learning (25-42). Hong Kong:HASALD.

Victori, M., \& W Lockhart. (1995). Enhancing metacognition in self-directed language learning. System, 23(2), 223-234.

Wenden, A. (2001). Metacognitive Knowledge in SLA: the neglected variable. In Breen, M 
(Ed.), Learner contributions to language learning (44-64). Harlow:Pearson Education Limited.

Yorozu, M. (2001). Interaction with native speakers of Japanese: what learners say. Japanese Studies, 21(2), 199-213.

\section{Glossary}

$\mathrm{EL}=$ English Language

ELP=English Language Proficiency

PGI $=$ Post graduate Intermediate

EAP $=$ English for Academic Purposes

ELS=English Language skill

OCLL=Out-of -class language learning

GTM=Grammar Translation method

\section{Appendix}

Appendix 1. Survey Question for study of intermediate Bengali medium students studying English at tertiary level in Bangladesh

Appendix 1 Survey Question

1. Please write your semester number here:

2. Gender: Male Female

3. Your age? (Years)

4. Nationality:

5. Are you working somewhere? Full/Part-time/No.

6. Where have you stayed during this course/year? (You may tick more than one) hostel Home-stay Flat or house.

7. Which language do you use MOST where you now stay? :

8. Yours most common way to be in touch of English: (ex: Movie, Books)

9. Yours favorite leisure time: 
10. Approximate amount of time u spend every day in touch of English:

(Example: 2 hours through a movie or 2.5 hours of study in gross everyday)

11. Most interesting way which connecting with English:

(Example: story books, study elements, watching movie, listening sports commentary etc.)

12. The way through you thinks you get developed your language skill most:

(Example: speaking with somebody, understanding the sub title etc.)

13. Which circle works as the deriving factor: Family Friends both?

14. Which way you think will be most useful and time consuming in the socio-economic Background of your country:

(Example: interactive movies or documentary, story books etc.)

\section{Copyright Disclaimer}

Copyright reserved by the author(s).

This article is an open-access article distributed under the terms and conditions of the Creative Commons Attribution license (http://creativecommons.org/licenses/by/3.0/). 